JPE (Jurnal Pendidikan Edutama) Vol. 6 No. 2 Juli 2019

P-ISSN : 2339-2258 (Print) E-ISSN: 2548-821X (Online)

http://ejurnal.ikippgribojonegoro.ac.id/index.php/JPE

\title{
STRATEGI PEMBELAJARAN BAHASA BAGI GENERASI Z: SEBUAH TINJAUAN SISTEMATIS
}

\author{
Helaluddin ${ }^{1}$ Harmelia Tulak ${ }^{2}$ Susanna Vonny N. Rante ${ }^{3}$ \\ ${ }^{1}$ Universitas Islam Negeri Sultan Maulana Hasanuddin Banten \\ Email: helaluddin@uinbanten.ac.id \\ ${ }^{2,3}$ Universitas Kristen Indonesia (UKI) Toraja, Sulawesi Selatan \\ 2Email: tulakharmelia@gmail.com \\ ${ }^{3}$ Email: vonnypgsd2017@gmail.com
}

\begin{abstract}
The purpose of this research is to describe about generation $Z$ and how lecturers should carry out learning on this generation. Systematic Literature Review (SLR) is used as a method of analyzing a wide range of articles and literature were obtained through searching of data sources such as google scholar, scopus, and ERIC. The results of the analysis of various sources elaborated reviews about the theory of generation, the $Z$ generation, and learning strategy for the $Z$ generation. The strategies are; (1) guided learning models, (2) visual and funbased learning, (3) optimize learning with applications and social media, (4) learning and creativity-oriented entrepreneurship, (5) optimize learning in groups, and (6) implement a blended learning system
\end{abstract}

Keywords: the generation of theory, $Z$ generation

\begin{abstract}
Abstrak
Tujuan dari penelitian ini adalah untuk mendeskripsikan tentang generasi $Z$ dan bagaimana seharusnya dosen melaksanakan pembelajaran terhadap generasi ini. Systematic Literature Review digunakan sebagai metode dalam menganalisis berbagai artikel dan literatur yang diperoleh melalui pencarian sumber data seperti google scholar, scopus, dan ERIC. Hasil analisis dari berbagai sumber tersebut dijabarkan ke dalam ulasan tentang teori generasi, generasi $Z$, dan strategi pembelajaran bagi generasi $Z$ tersebut. Berbagai strategi yang dimaksud tersebut adalah: (1) model pembelajaran terbimbing, (2) pembelajaran berbasis visual \& menyenangkan, (3) mengoptimalkan pembelajaran dengan aplikasi dan media sosial, (4) pembelajaran berbasis entrepreneurship \& kreativitas, (5) memaksimalkan pembelajaran dalam kelompok, dan (6) menerapkan blended learning.
\end{abstract}

Kata-kata kunci: teori generasi, generasi Z 


\section{PENDAHULUAN}

Bidang pendidikan merupakan aspek dalam kehidupan manusia yang memiliki jangkauan atau ruang kajian yang sangat luas. Pendidikan tidak dapat dilepaskan dari disiplin ilmu lain yang memiliki keterkaitan erat antara satu dengan yang lain, salah satunya adalah bidang sosiologi. Ilmu yang berkaitan dengan kehidupan sosial masyarakat ini terpaut dengan bidang pendidikan yang berperan penting pula dalam perkembangan dunia pendidikan. Salah satunya adalah teori generasi yang saat ini ramai diperbincangkan karena salah satu elemen pendidikannya, yaitu peserta didik tidak dapat dilepaskan dari teori ini.

Teori generasi erat kaitannya dengan berbagai istilah yang menjadi tren belakangan ini. Banyak istilah yang digunakan dalam menyebut kelompok generasi khususnya generasi muda. Istilah seperti generasi milenial, generasi zaman "now", generasi internet, dan lain-lainnya merupakan istilah yang kerap kita dengar saat ini. Istilah tersebut tidak muncul begitu saja tanpa ada latar belakang kajian ilmiahnya. Munculnya berbagai istilah tersebut tidakter lepas dari kajian teori generasi yang kian berkembang seiring dengan perubahan zaman dan kemajuan teknologi.

Teori generasi pertama kali dikemukakan oleh Karl Mannheim melalui berbagai penelitiannya dalam ranah sosiologi yang berkaitan dengan perkembangan nilai-nilai generasi pada tahun 1952. Mannheim mengungkapkan bahwa antara generasi muda dengan generasi tua memiliki gap atau jarak pembeda sehingga generasi muda memiliki kesulitan dalam bersosialisasi secara sempurna. Kesulitan tersebut biasanya berkaitan dengan nilai dan kebiasaaan generasi sebelumnya dengan generasi yang baru. Dengan demikian, gap tersebut menjadi suatu permasalahan yang timbul dan membutuhkan perhatian lebih dalam ranah akademis.

Pada perkembangannya, teori generasi digeneralisasikan menjadi beberapa kelompok generasi (cohort). Pengelompokan ini didasarkan pada persamaan peristiwa-peristiwa dan persamaan kurun waktu dalam setiap kelompok. Beberapa kelompok generasi tersebut adalah silent generation atau matures (<1946), baby boomers (1947-1964), generasi X (19651980), generasi $Y$ atau generasi milenial (1981-1995), generasi Z (1996sekarang) (Oblinger \& Oblinger dikutip Putra, 2016). Masing-masing generasi tersebut memiliki perbedaan karakteristik dan kepribadian. Dalam hal yang lebih spesifik (khususnya dalam bidang pendidikan dan pengajaran), tiap generasi memiliki perbedaan kecenderungan gaya belajar yang dimilikinya.

Perbedaan karakteristik dan gaya belajar inilah yang menjadi isu utama dalam pendidikan dan pembelajaran di era milenial. Banyak pendidik yang mengabaikan teori generasi dan tetap memaksakan mengajar dengan metode yang mereka peroleh masanya. Seperti diketahui bahwa metode pembelajaran pada zaman dahulu belum tentu efektif diberlakukan kembali pada generasi $\mathrm{Z}$ saat ini. Mengapa demikian? Generasi $\mathrm{Z}$ memiliki gaya belajar yang 180 derajat berbeda dengan generasi-generasi sebelumnya. Gaya belajar generasi ini terdiri atas: (1) learn from experimentation, (2) prefer visual learning, (3) like to work in group, (4) have short attention spans and multitask well, dan (5) edutainment (Mintasih, 2016). 
Kondisi pembelajaran di perguruan tinggi pun tidak jauh berbeda. Para dosen banyak yang mengabaikan teori generasi ini sehingga proses pembelajaran pun tidak berhasil secara maksimal. Dosen yang mayoritas berasal dari generasi X (sebagian kecil dari generasi baby boomers) memiliki perbedaan karakteristik yang sangat jauh dengan generasi para mahasiswa. Kondisi ini tentu menyebabkan kurang berterimanya gaya mengajar dosen bagi para mahasiswa saat ini. Banyaknya mahasiswa yang mengeluhkan tentang metode mengajar yang digunakan oleh dosennya merupakan salah satu indikasi dari kasus ini. Intinya, pembelajaran di sekolah dan perguruan tinggi sangat lambat perubahannya sehingga terjadilah gap yang begitu besar di antara kedua generasi tersebut (Swanzen, 2018).

Kesenjangan tersebut tidak dapat dikatakan sebagai permasalahan yang sederhana dalam dunia pendidikan saat ini. Mayoritas kampus yang masih menerapkan model pembelajaran konvensional tidak akan dapat mencapai tujuan pembelajaran secara maksimal. Prensky dikutip Jones \& Shao (2011) berargumen bahwa kesenjangan antara dosen sebagai digital immigrant dan mahasiswa sebagai digital natives menjadi masalah tunggal terbesar yang dihadapi dunia pendidikan saat ini. Dia menambahkan juga bahwa karakeristik dan preferensi mahasiswa saat ini sangat tidak sesuai dengan praktik mengajar para dosennya. Untuk itulah, dosen perlu mengubah pendekatan pembelajaran yang digunakan untuk memenuhi kebutuhan para generasi $\mathrm{Z}$ ini.

Hal yang lebih memprihatinkan justru banyak dosen yang tidak memahami tentang teori pendidikan dan pembelajaran. Mereka mengajar hanya didasarkan pada pengalaman ototidak dan pelatihan singkat seperti Program Peningkatan Keterampilan Dasar Teknik Instruksional (PEKERTI). Menurut Wibawanto (2016) sebagian besar dosen menceburkan diri ke dunia kampus justru tanpa membekali dirinya dengan ilmu dan teori pendidikan. Dengan demikian, seyogyanya seorang dosen harus mendalami/memahami tentang teori belajar dan pembelajaran agar mampu memberikan solusi dan metode terbaiknya dalam pembelajaran di kelas.

Kondisi di atas semakin diparah dengan berlakunya kebijakan research university yang hanya difokuskan pada bidang penelitian saja. Hampir semua perguruan tinggi berlomba-lomba mentransformasikan lembaganya menuju kampus riset kelas internasional. Namun di sisi lain, aspek pembelajaran justru dikesampingkan. Mayoritas kegiatan yang dilakukan dalam mengembangkan kompetensi dosen lebih banyak ditujukan pada pelatihan penelitian dan penulisan artikel jurnal internasional. Justru aspek penting dalam perguruan tinggi sebagai lembaga pendidikan dan pembelajaran cenderung dinomorduakan (Suganda, 2018).

Melihat situasi dan kondisi tersebut, seorang dosen harus segera memahami tentang karakteristik dan gaya belajar generasi Z. Pemahaman ini perlu segera dilakukan agar pembelajaran di kelas dapat berjalan dengan baik. Artikel ini mengulas berbagai strategi atau metode pembelajaran yang dapat digunakan oleh dosen di perguruan tinggi. Beberapa stretegi tersebut dikhususkan pada pembelajaran mata kuliah bahasa Indonesia sebagai Mata Kuliah Pengembangan Kepribadian (MPK). 


\section{METODE}

Metode yang digunakan dalam studi ini adalah Systematic Literature Review (SLR). Metode ini dianggap tepat untuk menghasilkan sebuah sintesis atau perpaduan berbagai literatur akademik yang andal dan akurat (Chalkiadaki, 2018). Pengumpulan data dilakukan dengan menggunakan google scholar, scopus, dan ERIC baik yang berupa artikel jurnal, buku, laporan, maupun artikel prosiding seminar. Semua data yang diperoleh tersebut dianalisis untuk disajikan dalam ulasan artikel ini secara menyeluruh dan terstruktur.

\section{PEMBAHASAN}

\section{Teori Generasi}

Ada beberapa ahli yang memperkenalkan teori generasi pada abad ke-20, antara lain Pierre Bourdieu (1977), Jose Ortega Y. Gasset (1958), Karl Mannheim (1952), dan Julian Marias (1970). Pada perkembangannya, teori generasi ini semakin populer pada tahun 1990-an melalui studi yang dilakukan oleh William Strauss dan Neil Howe. Menurut keduanya, kelompok generasi terbentuk karena telah dipengaruhi oleh berbagai faktor yang menyatu dan menjadi satu kesatuan.

Generasi adalah sekumpulan orang-orang pada suatu waktu yang diklasifikasikan dengan berdasarkan pada usia, tahun kelahiran, dan kejadian tertentu yang berpengaruh terhadap perkembangan dan kebiasaan hidup mereka. Menurut Glass dikutip Salleh, Mahbob, \& Baharudin (2017) generasi merupakan istilah tahun di mana individu atau kelompok individu yang hidup dan tinggal sehingga mereka memiliki gaya hidup sendiri. Definisi yang lain dikemukakan oleh Parry \& Urwin (2011) yang menyatakan bahwa generasi sebagai sebuah perangkat peristiwa sejarah dan fenomena yang dapat menciptakan kesenjangan generasi yang berbeda.

Di samping beberapa definisi di atas, masih ada teori lain yang dikemukakan oleh para ahli. Di satu sisi, Strauss dan Howe menyebutkan bahwa teori generasi diibaratkan seperti sebuah siklus sedangkan Mannheim menjabarkan teori generasi merupakan jenis identitas lokal tertentu yang berhubungan dengan kelompok umur yang ada pada proses sosial-historis (Padayachee, 2018). Lebih lanjut, Mannheim menyebutkan bahwa konsep generasi adalah sebuah aktualitas, yaitu pada saat dilahirkan mereka memiliki pengalaman serupa dan memandang diri mereka sebagai bagian dari generasi itu sendiri.

Pada perkembangannya, teori perbedaan generasi muncul dari berbagai hasil studi dan analisis para ahli. Terdapat perbedaan yang beragam dalam pengelompokkan generasi tersebut namun pada dasarnya memiliki beberapa persamaan. Ada beberapa faktor yang melatarbelakangi pengelompokkan generasi, salah satunya adalah faktor demografi dan faktor sosial. Faktor demografi berkaitan dengan pengelompokkan generasi yang didasarkan pada tahun kelahiran sedangkan faktor sosial berhubungan dengan persamaan kejadian-kejadian yang bersifat historikal.

\section{Generasi Z}

Seperti yang telah diuraikan di atas, komposisi atau cohort generasi dapat dikelompokkan dalam beberapa grup. Namun dari beberapa teori, ada 
perbedaan dalam menentukan kurun waktu tahun dalam pengelompokkannya. Salah satu kelompok generasi tersebut adalah generasi Z. Pada intinya, generasi Z yang menjadi topik dalam artikel ini muncul bersamaan dengan pesatnya laju perkembangan teknologi. Generasi ini dapat dikatakan hidup dan bernafas dengan teknologi. Artinya, teknologi bukanlah barang asing bagi generasi ini.

Generasi Z merupakan generasi yang lahir dari kurun tahun 1996 hingga tahun 2012 yang secara luas dikenal dengan julukan digital natives, megeneration, dan generasi $\mathrm{N}$. Turner (2015) mendefinisikan generasi $\mathrm{Z}$ sebagai generasi pertama yang terpapar secara luas dan langsung oleh penggunaan teknologi digital seperti situs jejaring sosial dan berbagai informasi yang berlebihan dari internet. Lebih lanjut, Khan \& Bansal (2018) menjabarkan bahwa generasi $\mathrm{Z}$ sebagai generasi yang tumbuh di era internet dan jaringan di seluruh dunia. Generasi ini dikarakteristikkan dengan fenomena 5,1 milyar pencari informasi di google per hari, 4 milyar penonton youtube, lebih 1 milyar pengguna akun facebook di seluruh dunia, dan lebih 1 milyar pengguna aplikasi musik iTunes.

Istilah digital natives sebagai sebutan lain dari generasi $\mathrm{Z}$ pertama kali dikemukakan oleh Marc Prensky pada tahun 2001. Menurutnya, generasi ini mendeskripsikan dirinya sebagai native speaker atau penutur asli dari bahasa digital pada komputer dan internet. Digital natives selalu dikonfrontasikan dengan digital immigrant yang didefinisikan sebagai generasi sebelumnya yang berupaya untuk belajar dan beradaptasi dengan teknologi. Namun yang patut digarisbawahi bahwa sebaik apapun para digital immigrant ini belajar dan menyesuaikan diri dengan kemajuan teknologi tetap saja mereka tidak dapat menghilangkan "aksen digital immigrant" tersebut (Jones \& Shao: 2011).

Menurut data terakhir tentang digital natives dikemukakan oleh Kemp (2018) melalui Google Consumer Behaviour bahwa ada sekitar 50\% total populasi di Indonesia merupakan pengguna internet. Dari sekitar 132 juta pengguna internet tersebut, setengahnya merupakan pengguna dari generasi $\mathrm{Z}$ atau digital natives. Data ini membuktikan bahwa generasi $\mathrm{Z}$ merupakan generasi terbesar di Indonesia sebagai "pengonsumsi" internet. Kondisi ini sejalan dengan data yang menyebut bahwa Indonesia menduduki peringkat 6 besar negara di dunia sebagai pengguna internet di bawah China, Amerika Serikat, India, Brazil, dan Jepang (Hidayat dikutip Supratman, 2018).

Menurut Salleh dkk. (2017) generasi $\mathrm{Z}$ lahir saat dunia mulai diguncang dengan isu terorisme hingga ketidakstabilan politik dan ekonomi dunia. Generasi ini melihat dan membaca langsung berbagai fenomena terorisme yang dimulai dari serangan 11 September pada menara kembar World Trade Center (WTC), berbagai perubahan iklim ekstrim hingga isu kesehatan dunia seperti serangan virus ebola, virus zika, dan flu burung. Bahkan, Seemiller dan Grace (dikutip Moore, Jones, \& Frazier, 2017) menyebut bahwa situasi tersebut menyebabkan generasi $\mathrm{Z}$ menjadi generasi yang tidak suka mengambil risiko (risk-taker).

Hal menarik yang perlu diulas tentang generasi $\mathrm{Z}$ adalah kecenderungan dan reaksi mereka terhadap berbagai isu global. Secara umum, anggota generasi ini cukup 
toleran bila dibandingkan dengan berbagai generasi sebelumnya. Di Amerika Serikat, generasi $\mathrm{Z}$ tumbuh dan berkembang saat terpilihnya presiden keturunan Afrika-Amerika yang pertama dan hadirnya kandidat presiden dari kaum perempuan (merebaknya isu kesetaraan gender di seluruh dunia). Generasi ini juga menyaksikan saat mahkamah agung atau pengadilan di beberapa negara melegalkan pernikahan sesama jenis yang sebelumnya masih dianggap menabrak norma-norma agama dan kemasyarakatan pada masa itu. Hal ini didukung oleh penelitian yang dilakukan oleh Northeastern University yang menyebutkan ada $73 \%$ generasi $\mathrm{Z}$ menyetujui jika di Amerika Serikat terdiri atas berbagai ras dan bahasa (Moore dkk., 2017). Bahkan, 73\% generasi ini juga mendukung hak perkawinan tanpa memandang orientasi seksual serta $74 \%$ jumlah generasi $\mathrm{Z}$ yang sepakat dan meyakini adanya persamaan hak bagi kaum transgender (waria).

Ilustrasi yang tidak kalah mencengangkan juga dikemukakan oleh beberapa ahli yang berkaitan dengan hadirnya generasi $\mathrm{Z}$ ini. Para ahli mengungkapkan bahwa ada perbedaan struktural antara generasi $\mathrm{Z}$ dengan generasi-generasi sebelumnya. Hal ini tidak disebabkan oleh faktor genetik namun disebabkan oleh faktor otak yang merespons lingkungan di luar mereka. Otak yang dimiliki oleh generasi Z seolah-olah seperti kabel yang canggih dan memiliki citra visual yang sangat kompleks (Rothman dikutip Cilliers, 2017). Dengan demikian, generasi $\mathrm{Z}$ akan lebih menyukai pembelajaran dalam bentuk visual karena bagian otak yang bertanggung jawab pada kemampuan ini dikembangkan dengan lebih baik dari bagian otak lainnya.

Generasi $\mathrm{Z}$ digambarkan sebagai pribadi yang memiliki pemahaman yang luas tentang perbedaan dan memiliki pikiran terbuka. Mereka terlahir dengan situasi yang berada dalam lingkungan perbedaan etnik, budaya, dan ras. Di samping itu juga, mereka dideskripsikan sebagai individu yang penyayang, bijaksana, tekun, dan bertanggung jawab (Hampton \& Keys, 2016). Kondisi tersebut menempa kepribadian dan pola pikir bagi generasi $\mathrm{Z}$ dalam memandang perbedaan ras, suku, budaya maupun agama dengan lebih terbuka. Mereka sudah terbiasa berinteraksi dan bersentuhan dengan lingkungan yang berbeda latar belakangnya.

Di samping sebagai generasi digital natives, generasi $\mathrm{Z}$ juga dikenal dengan istilah net generation, facebookgeneration, atau kadang-kadang disebut juga i-generation. Aspek lain yang menjadi identitas generasi $\mathrm{Z}$ adalah penggunaan bahasa, kata-kata, dan ekspresi dalam proses komunikasinya. Mereka kadang menggunakan bahasa dan ekspresi yang berbeda saat berinteraksi dengan kelompoknya dan dengan orang tuanya (Bencsik, Juhász, \& Horváth-Csikós, 2016). Jika dikaitkan dengan pengajaran dan pembelajaran, generasi $\mathrm{Z}$ memiliki karakteristik sebagai berikut: (1) digital integrator, (2) berjiwa entrepreneur, (3) dekat dengan keluarga, (4) percaya diri dan berpikiran terbuka, (5) mengutamakan kejujuran, (6) lebih beragam, (7) menginginkan umpan balik secepatnya, (8) lebih menyukai komunikasi personal kepada pengajar (Smith-Trudeau, 2016).

Uraian yang tidak jauh berbeda tentang karakteristik generasi $\mathrm{Z}$ juga dikemukakan oleh Grail (dikutip 
Hariadi, Dewiyani, \& Sudarmaningtyas, 2016). Beberapa karakteristik generasi $\mathrm{Z}$ yang dimaksud adalah: (1) sangat nyaman dan bebas dalam penggunaan teknologi, (2) multitasking terhadap berbagai produk daring (online) dan peralatan teknologi canggih, (3) memiliki rasa tanggung jawab sosial yang tinggi dengan banyak informasi yang diakses secara daring (dalam jaringan), (4) selalu terhubung dengan media sosial lintas negara dan lintas budaya.

Sebuah studi yang dilakukan oleh Northeastern University tentang generasi Z pada tahun 2014. Dari studi ini, mereka mengidentifikasikan ada lima kunci yang ditunjukkan oleh generasi ini, yaitu: a) memiliki jiwa entrepreneur yang kuat, bebas, dan semangat untuk mandiri dalam memetakan masa depan mereka, b) sangat mandiri dan memiliki perhatian yang lebih terhadap pendidikan tinggi dalam mencapai tujuan hidupnya, c) sangat peduli dengan keuangan termasuk biaya kuliah, d) meski sudah terhubung dengan teknologi dan media sosial namun mereka masih mementingkan interaksi antar-pribadi, e) sangat progresif dalam hal kebijakan sosial, mendukung sepenuhnya tentang kesehatan secara universal, memandang hak dan hukum yang sama bagi setiap orang, dan terlepas dari orientasi seksual (Conran dikutip Trevino, 2018).

Di samping lima kunci utama generasi $\mathrm{Z}$ yang dikemukakan oleh hasil studi dari Northeast University tersebut, Barley (dikutip oleh Hampton \& Keys, 2016) juga menyatakan ada beberapa poin penting yang berkaitan dengan generasi ini. Poin-poin penting tersebut adalah: (1) be real with generation $Z$, (2) celebrate generation $Z$ diversity, (3) care about the world as much as generation $Z$ does, (4) be brief when communicating with generation $Z$, dan (5) remain focused on the basics with generation $Z$.

Bersikap realistis terhadap generasi $\mathrm{Z}$ merupakan hal pertama yang harus dilakukan oleh pendidik. Pada konteks ini, mahasiswa selalu mengharapkan nilai dari pengalaman pendidikan dan bersiap untuk beralih ke dunia kerja yang menawarkan keamanan bagi mereka. Generasi Z ingin selalu belajar secara terusmenerus dan berharap dibimbing oleh dosen dan petugas kampus lainnya. Di sisi lain, pendidik bertugas untuk memastikan bahwa siswa-siswanya memahami nilai materi yang terkandung dalam mata kuliah dan memastikan bagaimana nilai tersebut berperan dalam kesuksesan karir mereka.

Kedua, pendidik harus merayakan dan menghargai aspek keberagaman bagi generasi Z. Perbedaaan merupakan hal yang wajar dan normal bagi generasi Z. Generasi ini sangat respek dan menghargai perbedaan ras, etnis, dan usia. Faktor ini memungkinkan mereka dapat berinteraksi dengan baik terhadap dosen dan petugas kampus yang berasal dari generasi yang berbeda. Generasi Z mengharapkan strategi yang berbeda yang ditawarkan oleh pihak kampus agar mereka merasa nyaman dalam proses pembelajaran. Salah satunya dengan penerapan strategi belajar kelompok.

Ketiga, pendidik harus peduli dengan apa yang dilakukan oleh generasi Z. Dosen dapat meluangkan waktunya untuk berdiskusi dalam 
situasi yang santai dalam membahasa berbagai isu kekinian. Dosen juga dapat turut serta dalam kegiatan kelompok atau komunitas mahasiswa untuk berbagi pengetahuan. Hal-hal yang disukai oleh generasi $\mathrm{Z}$ untuk didiskusikan antara lain topik tentang pencegahan penyakit, radikalisme, terorisme, kesehatan, dan lain-lain.

Keempat, lakukanlah komunikasi yang singkat dan efisien dengan para generasi Z. Jika dosen masih mempertahankan metode konvensionalnya dalam mengajar sangat kecil kemungkinan mahasiswa generasi $\mathrm{Z}$ tertarik. Pertemuan dalam perkuliahan yang panjang di kelas lalu mengharapkan mahasiswa untuk tetap fokus tidak akan membuahkan hasil yang baik. Pembelajaran harus dilakukan dengan integrasi dan modifikasi materi melalui variasi video maupun tampilan visual, streaming melalui youtube, dan lain-lain. Untuk itulah dosen cukup menyampaikan materi secara singkat lalu meminta mereka mengakses materi lebih lanjut melalui aplikasi maupun web pembelajaran yang disediakan oleh dosen/kampus.

Terakhir, dosen harus tetap memfokuskan perhatiannya pada dasardasar generasi Z. Pada poin ini, dosen dan petugas kampus harus berupaya keras membimbing mahasiswa generasi Z. Upaya pembimbingan ini berkaitan dengan usaha-usaha untuk meminimalisasi kekurangan generasi $\mathrm{Z}$. Seperti yang diuraikan di depan, generasi $\mathrm{Z}$ tidak terlalu memperhatikan detail informasi yang diperolehnya melalui interaksi teknologi digital. Untuk itulah, dosen harus bekerja ekstra keras dalam mengajarkan mahasiswa untuk berpikir kritis, memfilter data, dan menggunakan informasi yang diperolehnya untuk membuat keputusan yang baik.

\section{Strategi Pembelajaran pada Generasi Z}

Generasi $\mathrm{Z}$ yang memiliki karakteristik dan keunikannya sendiri tentu saja berpengaruh pula pada gaya belajarnya di kelas. Hal ini sudah banyak dibuktikan oleh para dosen yang mengeluh karena tidak diperhatikan saat menjelaskan di kelas. Dalam situasi ini, bisa saja mahasiswa (generasi Z) tidak tertarik lagi dengan strategi pembelajaran yang diterapkan oleh dosennya. Bahkan menurut Calvert (2018) sudah banyak studi dan penelitian yang menunjukkan bahwa mahasiswa atau generasi $\mathrm{Z}$ sudah tidak tertarik lagi mengikuti pembelajaran dengan pembelajaran pasif.

Dalam hal konsentrasi di kelas, generasi $\mathrm{Z}$ cenderung lebih singkat durasinya jika dibanding dengan generasi sebelumnya. Menurut Shatto \& Erwin (2016) rata-rata rentang perhatian generasi $\mathrm{Z}$ dalam pembelajaran di kelas hanya 8 detik sedangkan bagi generasi milenial memiliki rentang perhatian lebih lama, yaitu sekitar 12 detik. Singkatnya durasi atensi/perhatian mahasiswa generasi $\mathrm{Z}$ harus disiasati oleh setiap dosen dengan mengemas pembelajaran yang menarik dengan menyelipkan beberapa kali jeda dengan game atau permainan agar fokus mereka tetap terjaga.

Berbicara tentang kelebihan generasi $\mathrm{Z}$ tidak boleh dikesampingkan pula beberapa kelemahannya. Memahami kedua sisi ini akan 
memudahkan bagi tenaga pengajar untuk mencari solusi terbaik dalam pembelajaran. Kelebihan generasi $\mathrm{Z}$ yang memiliki kapasitas dalam mengakses informasi dengan cepat justru meninggalkan titik-titik kelemahan. Dengan kemampuan mengakses informasi yang cepat kadang-kadang mahasiswa generasi $\mathrm{Z}$ menemukan jawaban yang bersifat instan. Mereka bahkan tidak sampai menganalisis dan mengecek kebenaran jawaban yang dihasilkan atau ditemukannya (Hampton \& Keys, 2016). Ironisnya, dengan kemampuannya mengakses informasi secara cepat, mereka mengharapkan jawaban secara cepat pula. Bahkan mereka akan menjadi frustasi jika jawaban tidak ditemukan sesegera mungkin.

Generasi $\mathrm{Z}$ yang terlahir di era teknologi informasi dan digital akan mempengaruhi gaya belajar mereka. Kedekatan generasi ini dengan teknologi justru menjauhkan pada kebiasaan belajar dengan bahana ajar cetak (buku mata kuliahan atau buku pelajaran). Intensitas yang tinggi bagi generasi $\mathrm{Z}$ terhadap informasi mengakibatkan mereka menyukai belajar dengan observasi dan pengalaman visual dibandingkan dengan metode belajar konvensional seperti mendengarkan presentasi dosen di kelas dan kegiatan membaca.

Mengingat berbagai permasalahan tersebut maka strategi dan metode pembelajaran di perguruan tinggu harus segera didesain ulang (redesain). Ada beberapa hal yang menjadi faktor pemicu agar perguruan tinggi segera merombak pola pembelajarannya, yaitu: (1) adanya perbedaan yang cukup jauh (gap generasi) antara mahasiswa, dosen, dan pengelola kampus, (2) terdapat hubungan yang erat antara kualitas dosen dengan kualitas pembelajaran, (3) adanya perubahan yang cukup ekstrim dalam dunia kerja yang mayoritas didominasi oleh penggunaan teknologi, (4) jenis pekerjaan yang banyak mengalami perubahan, (5) gaya belajar tiap generasi berbeda-beda, (6) adanya pengaruh yang cukup kuat dari kemajuan teknologi dan informasi pada bidang pendidikan, dan (7) metode pembelajaran memang harus berubah sesuai dengan perubahan zaman (Suganda, 2018).

\section{Model Pembelajaran Terbimbing}

Salah satu karakteristik generasi $\mathrm{Z}$ adalah ketidaksukaannya terhadap pembelajaran yang hanya didasarkan pada kegiatan membaca dan menyimak (metode ceramah). Generasi ini lebih menyukai pembelajaran dengan pola pengamatan dan praktik langsung dan sangat impresif dalam mencari informasi melalui berbagai sumber secara daring. Namun di sisi lain, generasi ini memiliki kekurangan dalam menganalisis validitas sebuah informasi. Dalam hal ini, dosen harus selalu melakukan pengawasan dan bimbingan kepada mahasiswa dan mengembangkan kemampuan berpikir tingkat tinggi sebagai komponen dalam kesuksesan pembelajaran (Shatto \& Erwin, 2016).

Dalam kasus ini, dosen harus mampu menjadi fasilitator dalam mengarahkan mahasiswanya untuk mencari referensi informasi yang valid dan terpercaya. Kemampuan generasi $\mathrm{Z}$ dalam menghimpun informasi secara cepat pada kenyataanya tidak diimbangi dengan kemampuannya dalam menganalisis secara tepat. Banyak generasi $\mathrm{Z}$ yang menulis makalah dan artikel hasil menyalin dari berbagai situs di internet. Pada pembelajaran model terbimbing ini diharapkan dosen 
mampu mengarahkan mahasiswa untuk menghindari plagiarisme dengan memberikan tips dan trik-trik dalam aktivitas menulis akademik.

\section{Pembelajaran Berbasis Visual dan Menyenangkan}

Seperti yang telah dikemukakan sebelumnya, generasi $\mathrm{Z}$ memiliki struktur otak yang lebih mengedepankan pada perkembangan aspek visualnya. Untuk itulah, proses pembelajaran harus dikemas dengan menyajikan materi pelajaran secara visual. Hal ini tepat kiranya dilakukan karena generasi muda ini sangat mudah memahami segala sesuatu yang disajikan secara visual atau gambar yang menarik. Secara tegas Hilčenko (2017) menyebutkan bahwa "bahasa" generasi $\mathrm{Z}$ adalah gambar atau visual (their language is a picture).

Salah satu metode pembelajaran berbasis visual adalah penggunaan metode edutainment di kelas. Metode ini merupakan metode yang memangkas teknik-teknik konvensional seperti ceramah dan kegiatan mencatat dengan berbagai aktivitas yang lebih menarik dan menyenangkan. Metode edutainment merupakan metode pembelajaran dengan menggabungkan antara materi pembelajaran secara visual, bersifat narasi, pembelajaran dengan permainan, dan pengajaran dengan menggunakan gaya informal (Herawati dikutip Mintasih, 2016).

Pembelajaran dengan basis visual harus mengurangi deskripsi dan paparan secara berlebihan. Materi pembelajaran sedapat mungkin dikemas dengan uraian kalimat yang tidak terlalu panjang tetapi disubstitusi dengan berbagai gambar atau visualisasi yang menarik. Visualisasi yang dimaksud adalah tampilan materi yang dikemas dengan perpaduan foto (gambar), video (rekaman), ilustrasi bergerak, perpaduan warna yang menarik, dan pemilihan huruf serta ukurannya yang sesuai. Dengan penyajian yang menarik, mahasiswa generasi $\mathrm{Z}$ akan semakin tertarik dan memberikan perhatiannya pada proses pembelajaran.

Dalam pembelajaran mata kuliah bahasa Indonesia, pembelajaran dengan menggunakan basis visual dapat diterapkan dalam pembelajaran materi berbicara akademik dan non-akademik. Dosen dapat menayangkan contoh video seorang master ceremony atau pembawa acara dari youtube maupun situs web berbagi video lainnya. Dosen dapat memilih salah satu video atau lebih dengan mempertimbangkan tema, pembicara (model dalam video tersebut), dan hal-hal lainnya. Setelah menyaksikan tayangan video tersebut, dosen mengajak para mahasiswa untuk bersama-sama mengoreksi dan mengkritisi video tersebut. Dosen harus mengatur agar suasana pembelajaran tidak terlalu kaku atau formal agar mahasiswa tetap fokus dan tertarik mengikuti proses pembelajaran.

\section{Mengoptimalkan Pembelajaran dengan Aplikasi dan Media Sosial}

Generasi Z merupakan generasi yang tidak dapat dilepaskan dari gawai digital dan media sosial. Hampir semua jenis aplikasi sudah tertanam dalam gadget mereka, mulai dari aplikasi game, aplikasi musik, aplikasi startup, hingga media sosial. Dari beberapa hasil 
survei, diketahui bahwa generas $\mathrm{Z}$ atau digital natives setidaknya menggunakan $79 \%$ waktunya per hari dalam berinteraksi dengan smartphone-nya. Sedangkan akses mereka terhadap media sosial juga tidak tanggungtanggung. Pada tahun 2009, hasil survei menyatakan bahwa generasi ini minimal sepuluh kali mengakses media sosialnya dalam sehari, baik facebook, Instagram, WhatsApp, Line, Snapchat, Twitter, Ask.fm, Youtube, dan lain-lain.

Berkaitan dengan kondisi tersebut, Du Plessis menyatakan bahwa ada kebutuhan dalam mengeksplorasi dan memahami unsur-unsur teknologi, media sosial, dan jejaring sosial yang dimiliki oleh generasi Z (Cilliers, 2017). Hasil eksplorasi tersebut dapat diimplementasikan ke dalam sistem pendidikan dan pembelajaran di kelas. Hal ini tidak mengimplikasikan bahwa pengintegrasian teknologi sebagai bagian dari pembelajaran. Namun, ilustrasi di atas merupakan ide dosen dalam mencari mode pengaturan kelas yang kreatif dengan inisiatif unik dalam mengembangkan pembelajaran berbasis visual.

Mengingat tingginya tingkat interaksi generasi $\mathrm{Z}$ terhadap media sosial, tidak ada salahnya dosen mengembangkan dan memodifikasi pembelajaran dengan memanfaatkan media sosial tersebut. Di samping media sosial, dosen juga dapat memanfaatkan beberapa aplikasi yang sesuai dengan materi pembelajaran. Misalkan dalam pembelajaran kutipan (citation) dan bibliografi (daftar pustaka), dosen tidak perlu lagi mengajarkan materi secara manual namun dapat memanfaatkan beberapa aplikasi yang sengaja digunakan dalam aktivitas ini, seperti Mendeley, Zotero, Endnote, dan lainlain.

Dosen juga dapat menggunakan perangkat lain yang memang diperuntukkan untuk pembelajaran. Aplikasi yang dimaksud adalah LMS atau Learning Management System. Aplikasi ini merupakan sebuah perangkat lunak (software) yang menyediakan berbagai menu dalam proses pembelajaran dan pendidikan yang dimungkinkan untuk digunakan dalam jarak jauh sehingga mampu memfasilitasi antara dosen dan mahasiswa berinteraksi melalui internet. Beberapa jenis Learning Management System antara lain Edmodo, Moodle, Schoology, dan lain-lain.

Pembelajaran Berorientasi pada Entrepreneurship dan Kreativitas

Salah satu karakteristik yang menonjol bagi generasi $\mathrm{Z}$ adalah jiwa entrepreneur dan kreativitasnya dalam berbagai aktivitas. Hal ini sesuai dengan argumen Singh \& Dangmei (2016) yang menyebutkan generasi ini sebagai generasi yang lebih bersifat entrepreneur, dapat dipercaya, lebih toleran, dapat dipercaya, dan kurang termotivasi hal-hal yang berkaitan dengan uang. Lebih lanjut, ia juga menjabarkan bahwa generasi $\mathrm{Z}$ sebagai pribadi yang realistis terhadap ekspektasi dalam pekerjaanya dan optimis terhadap masa depan mereka. Dengan karakteristik tersebut, tidak mengherankan jika banyak para 
mahasiswa dari generasi ini sudah memiliki side job di luar aktivitas perkuliahannya. Beberapa aktivitas yang diminati oleh para digital natives ini antara lain content creator, youtuber, desainer grafis, dan lain-lain.

Berbicara tentang kreativitas, pembelajaran bahasa Indonesia dapat juga diarahkan ke ranah ini. Pada pembelajaran menulis non-akademik, seperti puisi, cerita pendek, maupun menulis catatan harian, dosen dapat mengarahkan mahasiswanya untuk membuat blog pribadi. Setelah itu, aktivitas dilanjutkan oleh mahasiswa dengan mem-posting puisi atau tulisan lain disertai dengan gambar menarik yang sesuai dengan tema tulisan (Burnet \& Fonder-Solano, 2018). Untuk materi membaca sastra, dosen dapat juga meminta kepada mahasiswa untuk mendaftar pada aplikasi Wattpad. Aplikasi ini merupakan aplikasi yang memuat beragam novel atau cerita fiksi yang memungkinkan untuk diunduh dan dibaca melalui smartphone. Bahkan jika memungkinkan, mahasiswa juga dapat mem-posting tulisan karya pribadinya pada aplikasi ini.

\section{Mengoptimalkan Pembelajaran dalam Kelompok}

Selain dekat dengan gawai teknologinya, generasi $\mathrm{Z}$ juga dikenal dengan ketertarikannya untuk bekerja dalam kelompoknya. Era pendidikan dengan aroma persaingan pada era-era sebelumnya sudah tidak dianggap efektif lagi karena hanya akan menimbulkan kompetisi antar peserta didik. Generasi $\mathrm{Z}$ sangat menyukai belajar dan bekerja secara berkelompok karena mereka merasa percaya diri dengan bekerja secara kolaboratif. Mintasih (2016) menyatakan bahwa kecenderungan generasi ini sejalan dengan teori Vygotsky yang disebut dengan zone of proximal growth theory. Dengan bekerja sama dengan rekanrekan sejawatnya, generasi ini akan mencapai puncak rasa percaya dirinya dan tanpa segan-segan mereka akan saling berbagi pengetahuan dengan teman satu kelompoknya.

Kolaborasi atau kerja kelompok di sini tidak hanya dalam konteks situasi yang nyata tetapi juga pada konteks dunia maya. Artinya, generasi $\mathrm{Z}$ sangat menyukai kerja bersama dengan fasilitas teknologi seperti video conference dan media komunitas yang lain. Hal ini sejalan dengan studi yang dilakukan oleh Scawbel yang menyatakan bahwa ada 53\% generasi $\mathrm{Z}$ yang lebih menyenangi komunikasi secara pribadi dengan menggunakan teknologi informasi seperti instant messaging dan konferensi dengan video (Hampton \& Keys, 2016). Hal tersebut juga sejalan dengan uraian Iorgulescu (2016) yang menemukan data bahwa siswa pada generasi ini menyukai kerja kelompok dengan sistem kolaborasi dan pengalaman bekerja secara tim yang bermakna.

\section{Menerapkan Sistem Blended Learning}

Salah satu sistem pembelajaran yang harus segera diterapkan saat ini adalah blended learning atau hybrid learning. Sistem pembelajaran ini merupakan pembelajaran kombinasi antara pembelajaran konvensional dengan pembelajaran daring (online). Artinya, dalam rencana pembelajaran satu semester dapat di-setting dengan dua jenis pertemuan, yaitu pertemuan ala konvensional atau tatap muka di kelas dan pertemuan via online. Dengan 
penggabungan ini diharapkan mahasiswa generasi $\mathrm{Z}$ lebih terpacu dalam proses pembelajaran.

Blended learning erat kaitannya dengan pembelajaran berbasis teknologi. Dosen dapat menggunakan beragam teknologi dalam proses pembelajaran mulai dari low technology hingga high technology. Jika fasilitas teknologi sudah memungkinkan, dosen dapat menggunakan tele-conference untuk menggantikan pertemuan tatap muka di kelas. Artinya, blended learning membuka peluang pembelajaran di mana saja dan kapan saja yang tidak terikat waktu dan tempat seperti pembelajaran konvensional.

Pembelajaran bahasa Indonesia dapat juga diapliksikan dalam pembelajaran blended learning ini. Penggunaan teknologi sederhana dari media sosial seperti facebook atau WhatsApp dapat digunakan jika dosen belum mampu mendesain pembelajaran berbasis laman (web-based learning). Dosen membuat grup WhatssApp atau grup dalam facebook berdasarkan kelas masing-masing lalu membagikan pranala atau link materi yang dapat diakses oleh mahasiswa di luar kampus. Dari link materi tersebut, dosen dapat memberikan tugas dan meminta mahasiswa mengirim tugas tersebut baik secara personal maupun di dalam grup tersebut.

\section{SIMPULAN}

Era generasi $\mathrm{Z}$ kini telah hadir di lingkungan kampus sebagai bagian dari dunia pendidikan yang harus mendapat perhatian lebih dari pihak perguruan tinggi. Generasi dengan karakteristik dan gaya belajar unik ini tentu tidak dapat disamakan dengan karakteristik pada generasi-generasi sebelumnya. Beberapa ahli menjelaskan bahwa generasi $\mathrm{Z}$ identik dengan generasi $\mathrm{Y}$, namun dalam beberapa aspek keduanya memiliki perbedaan yang cukup signifikan.

Adanya gap antara generasi dosen dan mahasiswa cenderung menyebabkan proses pembelajaran di perguruan tinggi tidak berjalan dengan baik. Pembelajaran yang ditawarkan oleh dosen dengan menggunakan metode konvensional dianggap tidak relevan lagi bagi generasi $\mathrm{Z}$ yang bersifat "digital banget". Kondisi inilah yang menyebabkan generasi $\mathrm{Z}$ sebagai mahasiswa cenderung tidak merespons dengan baik dalam pembelajaran di kelas.

Situasi ini harus segera disiasati oleh semua dosen dengan berupaya menyelami dan memahami karakteristik generasi Z. Selanjutnya, dosen dapat merancang strategi dan metode pembelajaran yang sesuai dengan kebutuhan generasi ini. Salah satunya dengan menggunakan pemanfaatan teknologi dalam proses pembelajaran di kelas. Generasi Z sebagai digital natives dianggap telah familiar dengan gadget dan gawai digital lainnya sehingga pembelajaran berbasis teknologi akan lebih mudah diterima bagi generasi ini.

\section{DAFTAR PUSTAKA}

Bencsik, A., Juhász, T., \& HorváthCsikós, G. (2016). $\mathrm{Y}$ and Z Generations at Workplaces. Journal of Competitiveness, 8(3), 90-106. https://doi.org/10.7441/joc.2016.03 .06 
Burnet, J., \& Fonder-Solano, L. (2018). Engaging I-gen Students in The Language Classroom. In $A F C$ International Conference on College Teaching and Learning. Mississippi: The University of Southern Mississippi.

Calvert, L. (2018). Effective Classroom Strategies for iGen. In Process Education Conference 2018 (pp. 13-14). Raymond: Hinds Community College.

Chalkiadaki, A. (2018). A Systematic Literature Review of $21^{\text {st }}$ Century Skills and Competencies in Primary Education. International Journal of Instruction, 11(3), 1-16.

Cilliers, E. J. (2017). the Challenge of Teaching Generation Z. PEOPLE: International Journal of Social Sciences, 3(1), 188-198. https://doi.org/10.20319/pijss.2017 .31 .188198

Hampton, D. C., \& Keys, Y. (2016). Generation Z Students: Will They Change Our Nursing Classrooms? Journal of Nursing Education and Practice, 7(4), 111-115. https://doi.org/10.5430/jnep.v7n4p 111

Hariadi, B., Dewiyani, M. J., \& Sudarmaningtyas, P. (2016). Development of Web-Based Learning Application for Generation Z. International Journal of Evaluation and Research in Education (IJERE), 5(1), 60-68. https://doi.org/10.11591/ijere.v5i1. 4523

Hilčenko, S. (2017). How Generation
"Z" Learns Better? European Journal of Social Sciences Education and Research, 11(2), 379. https://doi.org/10.26417/ejser.v11i 2.p379-389

Iorgulescu, M.-C. (2016). Generation Z and its Perception of Work. CrossCultural Management Journal, 18(1), 47-54.

Jones, C., \& Shao, B. (2011). The Net Generation and Digital Natives: Implications for Higher Education. Higher Education Academy. Milton Keynes: The Open University.

Kemp, S. (2018). Digital in 2018: Worlds' Internet Users Pass the 4 Billion Mark. Diunduh tanggal 1 Januari, 2019, dari https://wearesocial.com/blog/2018/ 01/global-digital-report-2018

Khan, I. A., \& Bansal, V. (2018). Effect of Using PC Tablets on Perceived Learning Outcomes of Generation $\mathrm{Z}$ Trainees. International Journal of Learning and Development, 8(1), 21-36. https://doi.org/10.5296/ijld.v8i1.12 309

Mintasih, D. (2016). Merancang Pembelajaran Menyenangkan. ElTarbawi Jurnal Pendidikan Islam, IX(1), 39-48. https://doi.org/10.20885/tarbawi.vo 19iss 1.art3

Moore, K., Jones, C., \& Frazier, R. S. (2017). Engineering Education For Generation Z. American Journal of Engineering Education, 8(2), 111125. 
https://doi.org/10.19030/ajee.v8i2. 10067

Padayachee, K. (2018). The Myths and Realities of Generational Cohort Theory on ICT Integration in Education: A South African Perspective. The African Journal of Information Systems, 10(1), 5485.

Parry, E., \& Urwin, P. (2011). Generational Differences in Work Values: A Review of Theory and Evidence. International Journal of Management Review, 73(1).

Salleh, M. S. M., Mahbob, N. N., \& Baharudin, N. S. (2017). Overview of "Generation $Z^{\text {" }}$ Behavioural Characteristic and its Effect towards Hostel Facility. International Journal of Real Estate Studies, 11(2), 59-67.

Shatto, B., \& Erwin, K. (2016). Moving from on Millennials: Preparing for Generation Z. The Journal of Continuing Education in Nursing, 47(6), 253-254.

Singh, A. P., \& Dangmei, J. (2016). Understanding The Generation Z: The Future Workforce. SouthAsian Journal of Multidisciplinary Studies (SAJMS), 3(3), 1-5. Diunduh dari https://www.researchgate.net/publi cation/305280948

Smith-Trudeau, P. (2016). Generation Z Nurses have Arrived. Are You Ready? Nursing News, 40(2), 13-
14.

Suganda, T. (2018). Pengelolaan Pembelajaran Generasi Z. Diunduh tanggal 3 Januari, 2018, dari

https://www.researchgate.net/publi cation $/ 323259147$

Supratman, L. P. (2018). Penggunaan Media Sosial oleh Digital Native. Jurnal Ilmu Komunikasi, 15(1), 47-60. Diunduh dari https://ojs.uajy.ac.id/index.php/jik/ article/view/1243/1152

Swanzen, R. (2018). Facing The Generation Chasm: The Parenting and Teaching of Generations $\mathrm{Y}$ and Z. International Journal of Child, Youth and Family Studies, 9(2), 125-150. https://doi.org/10.18357/ijcyfs9220 1818216

Trevino, N. G. (2018). The Arrival of Generation $Z$ on College Campuses. University of The Incarnate Word.

Turner, A. (2015). Generation Z: Technology and Social Interest. The Journal of Individual Psychology, 71(2), 103-112.

Wibawanto, H. (2016). Generasi Z dan Pembelajaran di Pendidikan Tinggi. Dalam Simposium "Mengenal dan Memahami Generasi Z. Haruskah Pendidikan Tinggi Berubah?" Bandung: Institut Teknologi bandung (ITB). 
46 JURNAL PENDIDIKAN EDUTAMA, Vol.6., No.2 Juli 2019 